\title{
Multiple Signal Transduction Mechanisms Leading to the Secretion of 5-Hydroxytryptamine by MTC Cells, a Neurectodermally Derived Cell Line
}

\author{
Hadassah Tamir, ${ }^{1,2}$ Kuo-peing Liu, ${ }^{1}$ Shu-chi Hsiung, ${ }^{1}$ Mella Adlersberg, ${ }^{1}$ Eladio A. Nunez, ${ }^{2}$ and Michael D. \\ Gershon ${ }^{2}$
}

'Division of Neuroscience, New York State Psychiatric Institute, New York, New York 10032, and 2Department of Anatomy and Cell Biology, Columbia University, College of Physicians and Surgeons, New York, New York 10032

Parafollicular (PF) cells of the thyroid gland are neural crest derivatives. These cells remain plastic even in adult animals and can be induced to exhibit neural properties when exposed to NGF in vitro. A human cell line derived from PF cells, medullary thyroid carcinoma (MTC), has previously been shown to synthesize and store 5-HT, a serotonin-binding protein (SBP), and several neuropeptides; moreover, when grown in impoverished media, MTC cells display neural properties. The purpose of the current study was to utilize MTC cells as a neurally relevant model system to investigate factors involved in mediating 5-HT secretion. Electron microscopic immunocytochemistry revealed that secretory vesicles of MTC cells costore immunoreactive 5-HT with SBP and calcitonin. The CAMP derivative, $\mathrm{N}^{6}$-2'-O-dibutyryladenosine $3^{\prime}, 5^{\prime}$-cyclic monophosphate (dibutyryl-cAMP; 1.0 $\mathrm{mM}$ ) increased the concentration of 5-HT in MTC cells and almost doubled the rate of synthesis of 5-HT from L-tryptophan. Dibutyryl-cAMP also significantly increased the secretion of $5-\mathrm{HT}$. Cycloheximide $(20 \mu \mathrm{g} / \mathrm{ml})$ and anisomycin $(20 \mu \mathrm{M})$ inhibited the dibutyryl-cAMP-induced increase of 5HT release, suggesting that this action of dibutyryl-cAMP requires protein synthesis. Cholera toxin $(1.0 \mu \mathrm{g} / \mathrm{ml})$ and forskolin $(0.05 \mathrm{~mm})$ in the presence of the phosphodiesterase inhibitor 3-isobutyl-1-methylxanthine $(1.0 \mathrm{~mm})$ both increased 5-HT biosynthesis and secretion. Attempts were made to identify a ligand that stimulates CAMP-mediated secretion of 5-HT. Both thyroid-stimulating hormone (TSH: $50 \mathrm{mU} / \mathrm{ml})$ and elevated $\left[\mathrm{Ca}^{2+}\right]_{e}(7.0 \mathrm{~mm})$, each of which acts as a secretogogue for PF cells, stimulated the secretion of 5-HT. The effect of TSH was $\mathrm{Ca}^{2+}$-dependent. Immunocytochemistry with monoclonal antibodies to the TSH receptor confirmed that these receptors are present on MTC cells.

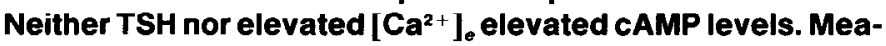
surements of Fura-2 fluorescence, however, indicated that both TSH and elevated $\left[\mathrm{Ca}^{2+}\right]_{e}$ increased cytosolic calcium $\left(\left[\mathrm{Ca}^{2+}\right]_{i}\right)$, as did elevation of $\left[\mathrm{K}^{+}\right]_{e}$. It is concluded that exo-

\footnotetext{
Received May 22, 1990; revised July 26, 1990; accepted July 27, 1990.

We wish to thank Dr. Micha Spira at the Howard Hughes Medical Institute, Columbia University, NY (present address, Hebrew University, Jerusalem, Israel) for testing the $\left[\mathrm{CA}^{2+}\right]_{i}$ with the video-imaging technique. This work was supported by NIMH Grant MH 37575 and NIH Grants NS 12969, NS 15547, and DK 19743.

Correspondence should be addressed to Dr. Hadassah Tamir, Division of Neuroscience, New York State Psychiatric Institute, 722 West 168 th Street, New York, NY 10032.

Copyright (C) 1990 Society for Neuroscience $0270-6474 / 90 / 113743-11 \$ 03.00 / 0$
}

cytosis can be triggered in MTC cells by multiple signal transduction mechanisms. Either CAMP or elevated $\left[\mathrm{Ca}^{2+}\right]_{i}$ can stimulate secretion; however, a secretogogue that increases cAMP has yet to be identified.

Parafollicular (PF) cells of the thyroid gland are neural crestderived endocrine cells that secrete calcitonin (Pearse, 1966; Bussolati and Pearse, 1967). During development (Gershon et al., 1971), and in several species also in adults (Falck et al., 1964; Jaim-Etcheverry and Zeiher, 1968; Gershon and Nunez, 1970; Nunez and Gershon, 1972; Machado, 1976), PF cells costore large amounts of 5-HT with calcitonin in the same subcellular secretory vesicles (Barasch et al., 1987a). Adult PF cells are quite plastic. When isolated and exposed to NGF, or cultured under appropriate conditions, they extend neuritic processes, express neurofilament protein, and change alternative splicing of mRNA transcribed from the calcitonin gene so that they synthesize calcitonin gene-related peptide (CGRP) instead of calcitonin (Barasch et al., 1987b). Medullary thyroid carcinoma (MTC) is a human tumor derived from PF cells (Leong et al., 1981). MTC cells in culture express many of the differentiated characteristics of PF cells, including synthesis and storage of calcitonin, CGRP, and 5-HT (Tamir et al., 1989). In contrast to PF cells, MTC cells do not have NGF receptors and so do not respond to NGF; however, when grown in the presence of lower than optimum concentrations of serum, MTC cells extend neurites, synthesize neurofilament proteins, and increase biosynthesis of CGRP (Tamir et al., 1989).

MTC cells can be used as models of serotonergic neurons (Tamir et al., 1989). Shared properties include synthesis of 5-HT from L-tryptophan, the uptake of exogenous ${ }^{3} \mathrm{H}-5-\mathrm{HT}$ by a high-affinity saturable transport mechanism that can be inhibited by fluoxetine or zimelidine, and secretory vesicles thiat accumulate 5 -HT by a mechanism that depends on a reserpinesensitive transporter. Finally, the secretory vesiclcs of MTC cells, like synaptic vesicles of serotonergic neurons, contain a highly specific 5-HT-binding protein, SBP (Barasch et al., 1987b; Tamir et al., 1989). As is also true of serotonergic neurons (Liu et al., 1987; Kirchgessner et al., 1988), both 45-kDa and 56$\mathrm{kDa}$ forms of SBP can be detected in MTC cells; the relative amounts of the 2 forms, $45 \mathrm{kDa}$ SBP $\gg 56 \mathrm{kDa}$ SBP, resemble the proportions seen in enteric serotonergic neurons and CNS synaptosomes rather than those found in the cell bodies of serotonergic neurons in the nuclei of the median raphe.

The current study was undertaken in order to study factors 
that regulate the storage and release of 5-HT by MTC cells. The ability of MTC cells to respond to secretogogues known to activate PF cells was investigated. Secretogogues studied included thyrotropin (TSH) and elevated $\left[\mathrm{Ca}^{2+}\right]_{e}$. In addition, the ability of CAMP to serve as a second messenger mediating the secretion of 5-HT was also examined. Our observations indicate that MTC cells, like PF cells, have TSH receptors, that MTC cells are stimulated to secrete $5-\mathrm{HT}$ by TSH and elevated $\left[\mathrm{Ca}^{2+}\right]_{e}$, and that secretion is also activated by elevation of intracellular cAMP. TSH and elevated $\left[\mathrm{Ca}^{2+}\right]_{e}$ increased free cytosolic $\mathrm{Ca}^{2+}$ concentration $\left(\left[\mathrm{Ca}^{2+}\right]_{i}\right)$, but failed to increase cAMP levels within the cells.

\section{Materials and Methods}

Tissue culture. MTC cells were propagated in culture as described previously (Tamir et al., 1989). Briefly, MTC cells were grown in $20 \times$ $100-\mathrm{mm}$ polystyrene tissue culture dishes $\left(4 \times 10^{6} \mathrm{cells} / \mathrm{dish}\right)$ or, for immunocytochemical studies, on glass coverslips (Corning, NY). Cells were grown in RPMI medium 1640 supplemented with $2 \mathrm{~mm}$ L-glutamine, $100 \mathrm{U}$ penicillin, $100 \mu \mathrm{g}$ streptomycin $/ \mathrm{ml}$, and $15 \%$ fetal bovine serum (FBS), all purchased from Gibco Laboratories (Grand Island, NY). After 1 wcck in vitro, the cells were harvested with $0.05 \%$ trypsin and $0.02 \%$ EDTA in PBS and, after inactivation of the trypsin with serum, were washed twice with PBS.

Assay of 5-HT and 5-HIAA. The assay is a slight modification of Mayer and Shoup (1983) and Kalivas and Miller (1985). In brief, aliquots of the media in which the cells were grown were acidified with $0.1 \mathrm{M}$ trichloroacetic acid (TCA), $0.1 \%$ cysteine (as an antioxidant), 0.01 M sodium acetate, and 18\% methanol (TCA/cysteine buffer; $\mathrm{pH}, 3.9$ ). Harvested cells were pelleted, then homogenized with a Polytron $\times$ the TCA/cysteine buffer. The homogenate was centrifuged for $5 \mathrm{~min}$ at $15,000 \times g$. The concentrations of 5-HT and 5-hydroxyindole acetic acid (5-HIAA) in aliquots of the supernatant were measured by reversephase high-pressure liquid chromatography (HPLC) using the above buffer as a mobile phase at a flow rate of $1 \mathrm{ml} / \mathrm{min}$. The electrochemical detcctor was set at $0.7 \mathrm{~V}$.

Secretion of 5-HT. Media was changed $24 \mathrm{hr}$ before the secretion of 5-HT was to be investigated. Just prior to addition of a potential secretogogue, the medium was aspirated from the dish, and monolayers were rinsed with $\mathrm{Ca}^{2+}$-free minimal essential medium (MEM with Hanks' salts; Gibco Laboratories). The cells were then incubated at $37^{\circ} \mathrm{C}$ in 5 ml MEM containing $3.0 \mathrm{mM} \mathrm{CaCl}$, for varying periods of time in the presence or absence of a secretogogue. In experiments where the effect of $\mathrm{Ca}^{2+}$-free media on the stimulated release of 5-HT was studied, MTC cells were maintained in Hanks' salts to which no $\mathrm{Ca}^{2+}$ was added. To test the effect of $\mathrm{Ca}^{2+}$ on the resting release of 5-HT, the cells were maintained in $5 \mathrm{ml}$ MEM to which $50 \mu \mathrm{M}$ EGTA was added "“zero" $\left[\mathrm{Ca}^{2+}\right]_{e} ;<1.3 \mathrm{~nm}$ ). Alternatively, the resting release was tested in solutions containing $3 \mathrm{mM} \mathrm{CaCl}_{2}$ in the presence or absence of $3.0 \mathrm{~mm}$ $\mathrm{CoCl}_{2}$, to block the uptake of $\mathrm{Ca}^{2+}$. In experiments where the dependence of 5-HT secretion on protein synthesis was examined, cells were pretreated with cycloheximide $(20 \mu \mathrm{g} / \mathrm{ml}$; Sigma Chemical Co., St. Louis, $\mathrm{MO})$ or anisomycin ( $20 \mu \mathrm{M}$; Sigma) for $30 \mathrm{~min}$ at $37^{\circ} \mathrm{C}$. In order to investigate the ability of cAMP to induce secretion, cells were exposed to the permeant derivatives, $N^{6}, 2^{\prime}-O$-dibutyryladenosine $3^{\prime}: 5^{\prime}$-cyclic monophosphate (dibutyryl-cAMP; $1 \mathrm{mM}$; Sigma) and 8-bromo-cAMP (Sigma). Both were dissolved in sterile medium immediately prior to use. Further experiments were performed with a water-soluble forskolin derivative [forskolin 7-deacetyl-7-(4-methylpiperazino)-butyryloxydihydrochloride $\cdot \mathrm{H}_{2} \mathrm{O} ; 0.05 \mathrm{~mm}$; Calbiochem, City, CA], which was dissolved in sterile water and added to cells together with 3-isobutyl-1methyl xanthine (IBMX; $1 \mathrm{~mm}$; Sigma). Cholera toxin $(1.0 \mu \mathrm{g} / \mathrm{ml}$; List Biol. Lab. Inc., Campbell, CA) was dissolved in $\mathrm{H}_{2} \mathrm{O}$. TSH $(50-500$ $\mathrm{mU} / \mathrm{ml}$; Sigma) was dissolved in PBS. In some experiments, the cells were preincubated with a monoamine oxidase inhibitor (pargyline; 10 $\mu \mathrm{M}$, Sigma) $30 \mathrm{~min}$ before studying the secretion of 5-HT. Following the addition of a potential 5-HT-releasing agent, an aliquot was removed from the medium and acidified, and its 5-HT and 5-HIAA contents were measured. At the end of each experiment, cells were rinsed thoroughly and harvested for cell counting. Alternatively, cells were acidified with TCA for assay of residual 5-HT and 5-HIAA. The release of 5-HT was measured as pmol 5-HT secreted per dish; the number of cells per dish was determined to be $3-4 \times 10^{6}$.

Pool of 5-HT released by dibutyryl-cAMP. In order to determine whether newly taken-up 5-HT is preferentially secreted the cells were loaded with ${ }^{3} \mathrm{H}-5-\mathrm{HT}(0.5 \mu \mathrm{M}, 12 \mathrm{Ci} / \mathrm{mm}$; Amersham, Arlington Heights, IL) for $1 \mathrm{hr}$ in MEM containing $3 \mathrm{mM} \mathrm{CaCl}_{2}$. The cells were then washed with PBS and exposed to dibutyryl-cAMP (1 mM). The concentrations of 5-HT and 5-HIAA were measured in the cells and in the ambient medium using HPLC with electrochemical detection as described above. The ${ }^{3} \mathrm{H}-5-\mathrm{HT}$ and ${ }^{3} \mathrm{H}-5-\mathrm{HIAA}$ content of cells and media were also determined by counting HPLC fractions, and the specific radioactivity of released 5-HT was calculated.

Effect of dibutyryl CAMP on the uptake of ${ }^{3} \mathrm{H}-5-\mathrm{HT}$. Monolayers were preincubated in the presence or absence of dibutyryl-cAMP (1.0 mM) for $4 \mathrm{hr}$ at $37^{\circ} \mathrm{C}$, followed by the addition of ${ }^{3} \mathrm{H}-5-\mathrm{HT}(0.5 \mu \mathrm{M}, 12 \mathrm{Ci} /$ mm) for 2, 5, 10, and $60 \mathrm{~min}$. In control experiments, the cells were incubated with ${ }^{3} \mathrm{H}-5-\mathrm{HT}$ at $4^{\circ} \mathrm{C}$. To stop the reaction, the pellets were washed twice with PBS, homogenized in TCA/cysteine buffer with a Polytron $\circledast$, and centrifuged $(10,000 \times \mathrm{g}, 5 \mathrm{~min})$. The supernatants were counted by liquid scintillation.

Effect of dibutyryl-cAMP on activity of MAO. The activity of MAO was measured using 5-HT as a substrate (Shie and Eiduson, 1973) so as to optimally assay MAO-A. MTC cells contain MAO-A, but little or no MAO-B (Tamir et al., 1989). Cells pretreated with dibutyryl-cAMP $\left(1 \mathrm{~mm}, 4 \mathrm{hr}, 37^{\circ} \mathrm{C}\right.$ ) were harvested, homogenized, and subjected to differential centrifugation and fractionated to prepare a crude mitochondrial pellet, which was used for determinations of enzymatic activity.

Effect of dibutyryl-cAMP on 5-HT biosynthesis. Tryptophan hydroxylase activity was measured by studying the conversion of ${ }^{3} \mathrm{H}-\mathrm{L}-\mathrm{tryp}-$ tophan to ${ }^{3} \mathrm{H}-5-\mathrm{HT}$. Because fetal bovine serum contains both tryptophan and 5-HT, cells $\left(4 \times 10^{6}\right)$ were suspended for the measurement of tryptophan hydroxylase in a low-serum-containing medium (NU. serum, Collaborative Research, Lexington, MA) supplemented with insulin, transferrin, selenium, and linoleic acid (ITS Premix, Collaborative Research). Cells were incubated at $37^{\circ} \mathrm{C}$ for 2,4 , and $8 \mathrm{hr}$ with ${ }^{3} \mathrm{H}$-L-tryptophan $(25 \mu \mathrm{M}, 50 \mathrm{Ci} / \mathrm{mm}$; Amersham), 6,7-dimethylpteridine ( $5 \mu \mathrm{M}$; Sigma), and pargyline ( $25 \mu \mathrm{M}$; Sigma) in the presence or in the absence of dibutyryl-cAMP ( $1 \mathrm{mM})$. Aliquots were removed from the media for measuring how much ${ }^{3} \mathrm{H}-5-\mathrm{HT}$ was released during the course of the incubation. At the end of each experiment, cells were harvested, washed twice with PBS, and homogenized in TCA/cysteine buffer. The homogenate was centrifuged $(15,000 \times \mathrm{g}, 5 \mathrm{~min}) .{ }^{3} \mathrm{H}-5-\mathrm{HT}$ and ${ }^{3} \mathrm{H}-5-$ HIAA in the supernatant and the media in which the cells were grown were separated from ${ }^{3} \mathrm{H}$-L-tryptophan by HPLC. The mobile phase used for HPLC in this experiment consisted of $0.1 \mathrm{M} \mathrm{NaH}_{2} \mathrm{PO}_{4}, 0.1 \mathrm{~mm}$ $\mathrm{Na}_{2} \mathrm{EDTA}$, and $6 \%$ methanol ( $\mathrm{pH}, 3.0$; adjusted with phosphoric acid). This solvent system was used at a flow rate of $1.1 \mathrm{ml} / \mathrm{min}$. The concentrations of 5-HT and 5-HIAA were determined by electrochemical detection. Fractions $(0.5 \mathrm{ml})$ were also collected into vials and counted by liquid scintillation spectrometry.

cAMP measurements. MTC cells were grown in 6-well dishes $(5 \times$ $10^{5}$ cells/well). Following incubation with secretogogues for $20 \mathrm{~min}$ at $37^{\circ} \mathrm{C}$ in the presence of IBMX (1 mM), the media was removed, and cAMP was extracted overnight at $4^{\circ} \mathrm{C}$ in $1.0 \mathrm{ml} 70 \%$ ethanol. The ethanolic extract was evaporated to dryness under $\mathrm{N}_{2}$ at $60^{\circ} \mathrm{C}$. The residue was then resuspended in $150 \mu \mathrm{l}$ assay buffer. cAMP was measured by radioimmunoassay, using a commercial kit (Amersham). Each sample was assayed in duplicate. Intraassay and interassay variation was less than $5 \%$ and $10 \%$, respectively. Protein content was measured in the ethanol-extracted cells, remaining on the plates on which they were grown. Cells were solubilized with $\mathrm{NaOH}(0.4 \mathrm{ml}, 0.05 \mathrm{M})$, and protein was determined colorimetrically (Bradford, 1976). In control experiments, a rat follicular cell line (FRTL-5 strain; Ambesi-Impiombato et al., 1980) supplied by Dr. Silvana Obici (Howard Hughes Medical Institute, Columbia University) was used. The FRTL- 5 cells $(4 \times$ $\left.10^{4}\right)$ were grown in Dulbecco's MEM (DMEM) supplemented with 5\% calf serum and hydrocortisone (10 nM), transferrin $(5 \mu \mathrm{g} / \mathrm{ml})$, glycyl-Lhistidyl-L-lysine acetate $(10 \mathrm{ng} / \mathrm{ml})$, somatostatin $(10 \mathrm{ng} / \mathrm{ml})$, insulin $(10$ $\mu \mathrm{g} / \mathrm{ml})$, and TSH $(2.5 \mathrm{mU} / \mathrm{ml}$; Gibco) for $5 \mathrm{~d}$. The cells were washed and maintained in the same medium without TSH for another $2 \mathrm{~d}$. Cells were then treated with TSH (50 mU) for $20 \mathrm{~min}$, and the levels of cAMP were measured as described above.

Determination of cytosolic Ca $\mathrm{Ca}^{2+}$ using Fura-2. MTC cells $\left(2 \times 10^{6} /\right.$ $\mathrm{ml}$ ) were suspended in Hanks' solution (without added $\mathrm{Ca}^{2+}$ ) containing BSA $(0.05 \%)$ and the acetoxymethyl ester of Fura-2 (Fura-2/AM; 5.0 

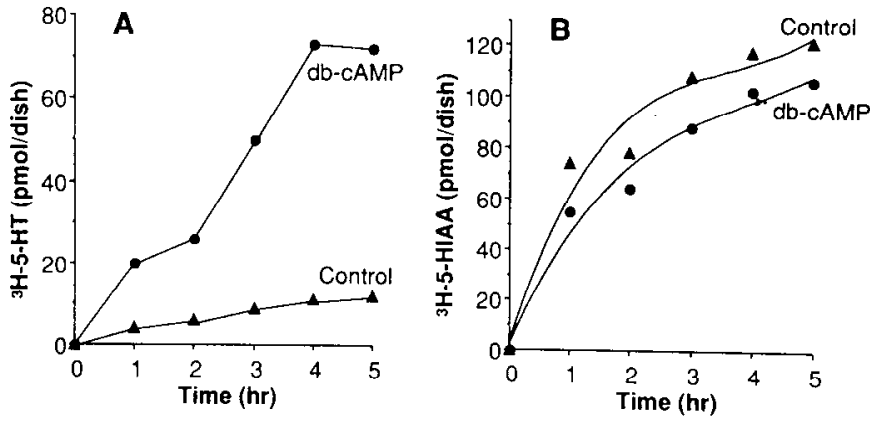

Figure 1. Dibutyryl-cAMP enhances release of ${ }^{3} \mathrm{H}-5-\mathrm{HT}$, but not ${ }^{3} \mathrm{H}$ 5-HIAA, from MTC cells. $A$, The release of ${ }^{3} \mathrm{H}-5$-HT from MTC cells $\left(4 \times 10^{6}\right)$ is plotted as a function of time in the presence $(d b-c A M P)$ or absence (control) of dibutyryl-cAMP. $B$, The release of ${ }^{3} \mathrm{H}-5$-HIAA from MTC cells $\left(4 \times 10^{6}\right)$ is plotted as a function of time in the presence $(\mathrm{db}$ $c A M P$ ) or absence (control) of dibutyryl-cAMP. The data represent an average of 3 separate experiments; errors represent too small a fraction of the mean to illustrate graphically.

$\mu \mathrm{M}$; Molecular Probes, Junction City, OR) at $37^{\circ} \mathrm{C}$ for $30 \mathrm{~min}$ (Grynkiewicz et al., 1985). The cells were then washed twice, diluted 5-fold in the same medium, and incubated for additional $20 \mathrm{~min}$ at $37^{\circ} \mathrm{C}$. After 1 further wash, the cells were suspended in Hanks' solution at a density of $2 \times 10^{6} / \mathrm{ml}$. For $\left[\mathrm{Ca}^{2+}\right]_{i}$ measurements, the cell suspensions were placed in cuvettes and stirred. Fura- 2 was excited with light at 380 and $340 \mathrm{~nm}$. The experimentally determined 340:380-nm fluorescence ratio is referred to as $R$. The maximum fluorescence ratio $\left(R_{\text {man }}\right)$ was measured after lysing the cells at the end of the experiment with digitonin $(50 \mu \mathrm{M}$ Sigma) and adjusting the $\left[\mathrm{Ca}^{2+}\right]_{e}$ levels to $1.5 \mathrm{~mm}$. The minimum fluorescence ratio $\left(R_{\mathrm{min}}\right)$ was measured after the addition of EGTA (10 mM; Sigma) and enough Tris base $(1 \mathrm{M})$ to adjust the $\mathrm{pH}$ to $>8.2$. The $340: 380-\mathrm{nm}$ ratios were converted to free $\mathrm{Ca}^{2+}$ concentrations, $\left[\mathrm{Ca}^{2+}\right]_{i}$ by using the equation of Grynkiewicz et al. (1985).

Fura- 2 imaging. The effect of TSH on $\left[\mathrm{Ca}^{2+}\right]_{i}$ in individual MTC cells was studied using optical imaging of cells loaded with Fura-2. In these experiments, the cells were grown on glass coverslips and were not detached prior to loading with Fura-2 (as described above). The apparatus used for recording intracellular $\mathrm{Ca}^{2+}$ has previously been described (Blumenfeld et al., 1990). In brief, cells were visualized with a Zeiss IM-35 inverted microscope fitted with a Hamamatsu C2400 SIT camera. Fluorescence images were digitized and analyzed using a PC Vision frame grabber and a Del personal computer. The computer was also used to control the filter changer and shutters. Ratio measurements were performed by switching excitation wavelength bandpath filters ( 340 and $380 \mathrm{~nm}$ ) and recording the emitted fluorescence at $505 \mathrm{~nm}$. Relative calcium concentrations were depicted as pseudocolor images. No attempt was made to convert the data to absolute values of $\left[\mathrm{Ca}^{2+}\right]_{i}$. Pseudocolor representations were displayed on a high-resolution TV monitor (Sony) and photographed.

Electron microscopic immunocytochemical demonstration of calcitonin, 5-HT, and SBP. This was performed as previously described (Barasch et al., 1987b). In brief, MTC cells were fixed for $3 \mathrm{hr}$ at $4^{\circ} \mathrm{C}$ in a mixture consisting of $4 \%$ formaldehyde and $0.1 \%$ glutaraldehyde in 0.1 M sodium phosphate buffer ( $\mathrm{pH}, 7.4$ ) containing 3\% sucrose and embedded in the hydrophilic resin LR White (Ernest Fullam, Schenectady, NY). Thin sections were immunostained with a rat monoclonal antibody to $5-\mathrm{HT}(50 \mu \mathrm{g} / \mathrm{ml}$; Seralabs, Westbury, NY), a rabbit polyclonal antiserum to human calcitonin (Immunonuclear Corp., Sillwater, MN), or a rabbit polyclonal affinity-purified antibody to 45-kDa SBP (Barasch et al., 1987b). Species-specific secondary antibodies coupled to $5-\mathrm{nm}$ (5-HT; goat anti-rat; Janssen Pharmaceutical Co., Bearse, Belgium) or 15-nm (calcitonin or SBP; goat anti-rabbit) particles of colloidal gold permitted 5-HT immunoreactivity to be visualized simultaneously with that of calcitonin.

Immunocytochemical detection of TSH receptors. MTC cells were fixed in a solution consisting of $4 \%$ formaldehyde in $0.1 \mathrm{M} \mathrm{PBS} \mathrm{pH}$, 7.4). Two monoclonal antibodies (MAbs) that have been shown to bind to rat TSH receptors were obtained. One (52A8) was supplied by Dr. Silvana Obici (Howard Hughes Medical Institute, Columbia University), and the other by Dr. Bernard Erlanger (Department of Microbiology, Columbia University). Both MAbs were diluted (1:1) with $0.1 \mathrm{M}$
PBS and applied to intact fixed monolayers of MTC cells for $2 \mathrm{hr}$ at room temperature. Cells were not permeabilized. Sites of bound antibody were localized with a biotinylated goat anti-mouse antibody (diluted 1:200-400; Kirkegaard and Perry, Gaithersburg, MD) and visualized with avidin conjugated to fluorescein isothiocyanate (avidin-FITC; Vector Laboratories, Gaithersburg, MD).

Statistical analysis. Student's $t$ test was used to compare sample means. Unless otherwise stated, all results are presented as means \pm the standard error of the mean. Differences between means were considered significant if the probability that the observed difference could be due to chance was $<0.05$.

\section{Results}

Effect of dibutyryl-cAMP on ${ }^{3} \mathrm{H}-5-\mathrm{HT}$ release from $M T C$ cells Cells were loaded with ${ }^{3} \mathrm{H}-5-\mathrm{HT}(0.1 \mu \mathrm{M})$ and washed until ${ }^{3} \mathrm{H}-$ 5-HT washing out of the cells was minimal and relatively constant. The washed cells were then incubated in the presence or absence of dibutyryl-cAMP (1.0 mM). At intervals of $1-5 \mathrm{hr}$, aliquots of media were sampled and assayed to determine both the radioactivity of ${ }^{3} \mathrm{H}-5-\mathrm{HT}$ and ${ }^{3} \mathrm{H}-5-\mathrm{HIAA}$ and the total 5-HT and 5-HIAA content. At the end of the experiment, the radioactivity of ${ }^{3} \mathrm{H}-5-\mathrm{HT}$ and ${ }^{3} \mathrm{H}-5-\mathrm{HIAA}$ and the concentrations of 5-HT and 5-HIAA remaining in the cells were measured. Dibutyryl-cAMP was found to increase the amount of ${ }^{3} \mathrm{H}-5-\mathrm{HT}$ in the ambient medium (Fig. 1A). This apparent release of ${ }^{3} \mathrm{H}-5-\mathrm{HT}$ was maximal $4 \mathrm{hr}$ after the addition of dibutyryl-cAMP. In contrast, no increase in the amount of ${ }^{3} \mathrm{H}$ 5-HIAA was induced by dibutyryl-cAMP (Fig. 1B). Like dibutyryl-cAMP, 8-bromo-cAMP also appeared to release ${ }^{3} \mathrm{H}-5$ HT but not ${ }^{3} \mathrm{H}-5$-HIAA (data not shown). When cells were incubated with dibutyryl-cAMP, about 2.5 times as much 5 $\mathrm{HT}$ was recovered from the medium as was found inside the cells at the end of the incubation period. In contrast, the amount of 5-HT in the medium of cells incubated in the absence of dibutyryl-cAMP was only 0.35 times that found within the cells at the end of the experiments. This $>7$-fold increase in the ratio of media 5-HT to that remaining in cells induced by dibutyrylcAMP was highly significant $(p<0.001)$. In control experiments, incubated for $5 \mathrm{hr}$ in the absence of dibutyryl-cAMP, the specific radioactivity of ${ }^{3} \mathrm{H}-5$-HT remaining in the cells was $1260 \pm 190 \mathrm{cpm} / \mathrm{pmol}$, whereas that of ${ }^{3} \mathrm{H}-5-\mathrm{HT}$ in the medium was $2300 \pm 200 \mathrm{cpm} / \mathrm{pmol}(p<0.001, n=5)$. In experiments in which cells were incubated for $5 \mathrm{hr}$ in the presence of dibutyryl-cAMP, the specific radioactivity of ${ }^{3} \mathrm{H}-5-\mathrm{HT}$ remaining in the cells was $1000 \pm 98 \mathrm{cpm} / \mathrm{pmol}$, while that of ${ }^{3} \mathrm{H}-5-\mathrm{HT}$ in the medium was $1920 \pm 210 \mathrm{cpm} / \mathrm{pmol}(p<0.001, n=5)$. These observations suggest that dibutyryl-cAMP releases 5-HT, and that newly taken-up amine is preferentially released both under resting and dibutyryl-cAMP-stimulated conditions.

\section{Effect of dibutyryl-cAMP on uptake of ${ }^{3} \mathrm{H}-5-H T$ by MTC cells}

Because a resting release of ${ }^{3} \mathrm{H}-5-\mathrm{HT}$ was observed, it is conceivable that the increase in ${ }^{3} \mathrm{H}-5-\mathrm{HT}$ observed in the media of cells exposed to dibutyryl-cAMP was the result not of the secretion of ${ }^{3} \mathrm{H}-5-\mathrm{HT}$, but of a reduction in its reuptake. The effect of dibutyryl-cAMP (1.0 mM) on the uptake of ${ }^{3} \mathrm{H}-5-\mathrm{HT}$ by MTC cclls was therefore determined. Uptake of ${ }^{3} \mathrm{H}-5-\mathrm{HT}$ was found to be linear for up to $7 \mathrm{~min}$. The amount of ${ }^{3} \mathrm{H}-5-\mathrm{HT}$ taken up by the cells in 5 min was measured and used as an estimate of the initial rate of ${ }^{3} \mathrm{H}-5-\mathrm{HT}$ uptake $\left(1.2 \pm 0.2 \mathrm{pmol} / 10^{6}\right.$ cells $/$ $\min , n=4)$. This rate was unchanged by preincubating the cells for $4 \mathrm{hr}$ with dibutyryl-cAMP $\left(1.4 \pm 0.2 \mathrm{pmol} / 10^{6} \mathrm{cells} / \mathrm{min}\right.$, $n=4$ ). 


\section{Effect of dibutyryl-cAMP on synthesis of 5-HT by MTC cells}

In the experiments on the release of 5-HT, it was noted that the total recovery of 5-HT was 2-fold greater when preparations were exposed to dibutyryl-cAMP than when they were not ( $p$ $<0.001)$. This increase suggests that dibutyryl-cAMP stimulates the biosynthesis of 5-HT. Such an effect of dibutyryl-cAMP on 5-HT biosynthesis in MTC cells has previously been found in cells grown in impoverished media (Tamir et al., 1989); however, under these conditions most cells die and levels of 5-HT are extremely low. In the current study, MTC cells were grown in enriched media in which cell survival is optimal. Because FBS, which contains 5-HT, is a constituent of enriched media, cells werc transferred to MEM immediatcly before the start of experiments on the biosynthesis of 5-HT. MTC cells grown under these conditions were found to have high levels of 5-HT (5-25 pmol $/ 10^{6}$ cells) and to survive well for several $\mathrm{hr}$ after transfer to MEM.

The effect of dibutyryl-cAMP on the biosynthesis of 5-HT was analyzed by incubating MTC cells with ${ }^{3} \mathrm{H}$-L-tryptophan in the presence or absence of dibutyryl-cAMP. A preliminary experiment was performed first to ascertain whether exposure of MTC cells to dibutyryl-cAMP affected their MAO activity. MAO activity was not changed when cells were incubated in the presence of dibutyryl-cAMP for up to $4 \mathrm{hr}$ (data not illustrated); therefore, any dibutyryl-cAMP-induced change in the amount of ${ }^{3} \mathrm{H}-5$-HT in cells (and/or medium) incubated with ${ }^{3} \mathrm{H}$-L-tryptophan would have to be due to an effect of dibutyryl-cAMP on the biosynthesis of ${ }^{3} \mathrm{H}-5-\mathrm{HT}$ and not the catabolism of ${ }^{3} \mathrm{H}-$ 5 -HT. After $4 \mathrm{hr}$ of incubation with ${ }^{3} \mathrm{H}-\mathrm{L}$-tryptophan, the total 5-HT content and the amount of ${ }^{3} \mathrm{H}-5-\mathrm{HT}$ were each measured in the cells and in the ambient medium. ${ }^{3} \mathrm{H}-5-\mathrm{HT}$ synthesized from ${ }^{3} \mathrm{H}$-L-tryptophan was found to increase in both cells and media for $4 \mathrm{hr}$. After $4 \mathrm{hr}$ in the absence of dibutyryl-cAMP, $40.3 \pm 8.1$ pmol ${ }^{3} \mathrm{H}-5-\mathrm{HT}$ were found in the cells, and $9.5 \pm$ $1.2 \mathrm{pmol}{ }^{3} \mathrm{H}-5-\mathrm{HT}$ were found in the medium. When cells were exposed to dibutyryl-cAMP, $83.0 \pm 8.2$ pmol ${ }^{3} \mathrm{H}-5-\mathrm{HT}$ were found in the cells, and $42.8 \pm 9.1$ pmol ${ }^{3} \mathrm{H}-5-\mathrm{HT}$ were found in the medium. Dibutyryl-cAMP thus significantly increases the biosynthesis of ${ }^{3} \mathrm{H}-5$-HT from ${ }^{3} \mathrm{H}$-L-tryptophan $(p<0.02)$.

\section{Dependence of the effects of dibutyryl-cAMP on protein synthesis}

The involvement of protein synthesis in mediating the effects of dibutyryl-cAMP on the release and production of 5-HT by MTC cells was tested by examining the ability of cycloheximide and anisomycin to inhibit these effects. The dibutyryl-cAMPinduced increase in the release of 5-HT was found to be prevented when cells were treated with cycloheximide (Fig. $2 A$ ) or anisomycin (not shown). Exposure to cycloheximide alone also increased the total amount of 5-HT present in cells and media (Fig. 2B). A similar increase in 5-HT was noted when cells were exposed to anisomycin instead of cycloheximide (data not shown). The increase in 5-HT induced by cycloheximide was of the same magnitude as that which followed incubation with dibutyryl-cAMP. When cells were incubated with both cycloheximide and dibutyryl-cAMP, the 5-IIT content of cells and media was again elevated; however, the effects of cycloheximide and dibutyryl-cAMP were not additive. The rise in 5-HT following exposure to the combination of cycloheximide and dibutyryl-cAMP was comparable to that seen after exposure of cells to either of these agents alone. These observations suggest
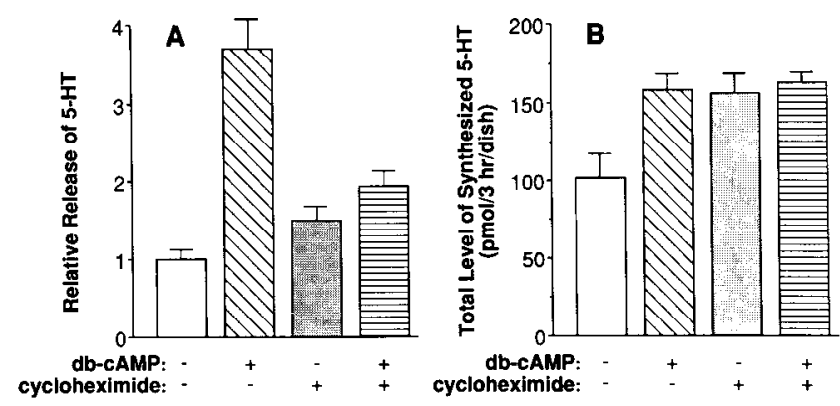

Figure 2. Inhibition of protein synthesis with cycloheximide antagonizes dibutyryl-cAMP-induced release of 5-HT from MTC cells, but promotes synthesis of 5-HT. $A$, The relative release of 5-HT by MTC cells incubated for $3 \mathrm{hr}$ in the presence (pluses) or absence (minuses) of cycloheximide and dibutyryl-cAMP is plotted. Relative release is defined as a multiple of the amount of 5-HT released in the absence of either cycloheximide or dibutyryl-cAMP ( $55 \mathrm{pmol} / 3 \mathrm{hr} / \mathrm{dish}) . B$, MTC cells were incubated for $3 \mathrm{hr}$ under the conditions indicated on the abscissa. The level of 5-HT present in cells and media was measured and added together. A rise in this level under experimental conditions is an indicator of increased 5-IIT biosynthesis. Each bar represents the mean of 4 separate experiments.

that the dibutyryl-cAMP-induced release of 5-HT from MTC cells is dependent on new protein synthesis. Because inhibitors of protein synthesis themselves appeared to increase the biosynthesis of 5-HT, no conclusions can be drawn as to the dependence of the 5-HT biosynthesis-promoting effect of dibutyryl-cAMP on protein synthesis.

\section{$\mathrm{Ca}^{2+}$ dependence of the effects of dibutyryl-cAMP}

We studied the resting and dibutyryl-cAMP-stimulated release of 5-HT from MTC cells incubated in MEM with or without added $3.0 \mathrm{mM} \mathrm{Ca}^{2+}$. The addition of $\mathrm{Ca}^{2+}$ to the medium had no effect on the resting release of 5-HT; however, the ability of dibutyryl-cAMP to increase the release of 5-HT to the media was dependent on the addition of $\mathrm{Ca}^{2+}$ (Fig. $3 A$ ). In order to examine the effect of $\mathrm{Ca}^{2+}$ on the production of 5-HT, MTC cells were or were not exposed to dibutyryl-cAMP in media to which $\mathrm{Ca}^{2+}$ was or was not added, and the total amount of 5-IIT recovered from the cells and medium was determined (Fig. 3B). Addition of $\mathrm{Ca}^{2+}$ did not itself appear to affect the production of 5-HT; however, the increase in 5-HT that accompanied exposure of cells to dibutyryl-cAMP only occurred when $\mathrm{Ca}^{2+}$ was added to the medium. Media to which no $\mathrm{Ca}^{2+}$ was added was not $\mathrm{Ca}^{2+}$ free. The concentration of $\mathrm{Ca}^{2+}$ in this media was measured with a calcium electrode and was found to be 10 $\mu \mathrm{M}$. In order to test the $\mathrm{Ca}^{2+}$ dependence of the resting release of $5-\mathrm{HT}$, therefore, the medium was titrated to $1.0 \mathrm{~nm}$ with the calcium chelating agent EGTA (Adlersberg et al., 1987). This procedure reduced the release of 5 -HT by $35 \pm 5 \%(p<0.05)$. This observation suggests that the resting release of 5-HT is partially $\mathrm{Ca}^{2+}$ dependent. This suggestion was confirmed by adding $\mathrm{Cd}^{2+}(1.0 \mathrm{mM})$ to the medium. Again, the resting release of 5 -HT was reduced by $35 \pm 5 \%$.

\section{Effects of forskolin and cholera toxin on the release of 5-HT}

In order to confirm that the effects of dibutyryl-cAMP were specific, cAMP levels within MTC cells were raised by alternative means. Cells were exposed to forskolin to activate adenylate cyclase directly (Seamon and Daly, 1983). IBMX was also added to prevent the breakdown of cAMP by phospho- 

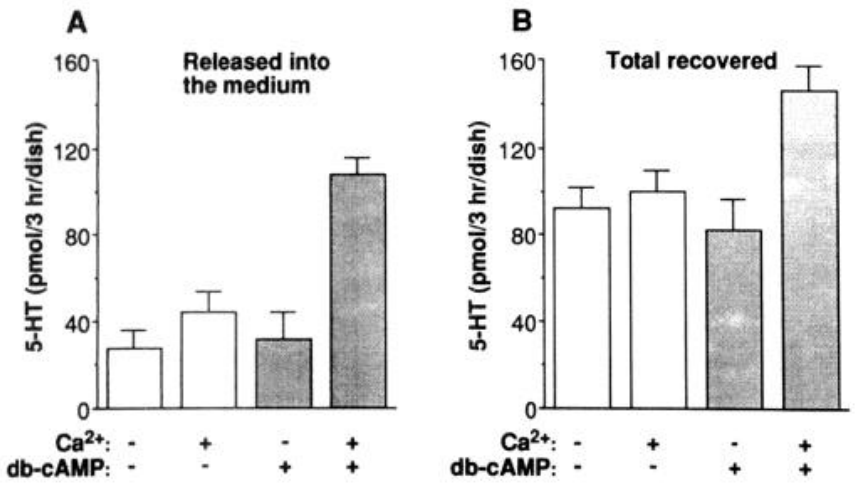

Figure 3. The dibutyryl-cAMP-induced release of 5-HT from MTC cells is $\mathrm{Ca}^{2+}$ dependent. $A$, The release of 5-HT to the ambient medium is plotted for MTC cells incubated for $3 \mathrm{hr}$ in the presence (pluses) or absence (minuses) of dibutyryl-cAMP and/or $\mathrm{Ca}^{2+} . B$, The total recovery of 5-HT in the cells and medium is plotted for MTC cells incubated for $3 \mathrm{hr}$ under the experimental conditions indicated on the abscissa. Each bar represents the mean of 5 separate experiments.

diesterase. Like dibutyryl-cAMP, forskolin, in the presence of IBMX, increased both the release (Fig. $4 A$ ) and production of 5-HT (Fig. 4B). Each of these actions of forskolin and IBMX was only seen when $\mathrm{Ca}^{2+}(3.0 \mathrm{~mm})$ was added to the medium. Cholera toxin (Gill and Meren, 1978) also increased the release (Fig. $5 A ; p<0.001, n=12$ ) and total recovery (Fig. $5 B ; p<$ $0.05, n=6$ ) of 5 -HT. It is concluded that elevated levels of intracellular cAMP promote the $\mathrm{Ca}^{2+}$-dependent release and increased biosynthesis of 5-HT. The effect of cholera toxin, moreover, suggests that activation of adenylate cyclase in MTC cells is mediated by a member of the $\mathrm{G}_{\mathrm{s}}$ class of GTP-binding protein. It is not clear why cholera toxin is apparently less effective than cAMP analogs and forskolin. Similar effects of cholera toxin were obtained at concentrations of 1,10 , and $100 \mu \mathrm{g} /$ $\mathrm{ml}$. Differences between substances may be related to differing rates at which each penetrates plasma membranes.
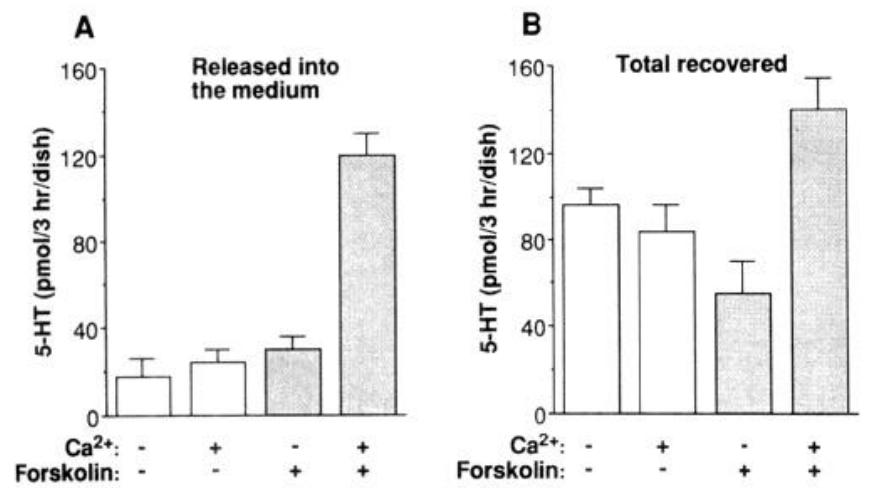

Figure 4. Forskolin increases both release of 5-HT from MTC cells and its biosynthesis; both effects are $\mathrm{Ca}^{2+}$ dependent. $A$, The release of 5 -HT to the ambient medium is plotted for MTC cells incubated for 3 $\mathrm{hr}$ in the presence (pluses) or absence (minuses) of forskolin and/or $\mathrm{Ca}^{2+}$. $B$, The total recovery of $5-\mathrm{HT}$ in the cells and medium is plotted for MTC cells incubated for $3 \mathrm{hr}$ under the experimental conditions indicated on the abscissa. In the presence, but not the absence, of $\mathrm{Ca}^{2+}$, forskolin induced an increase in the recovered 5-HT; therefore, the forskolin-induced enhancement of 5-HT biosynthesis is $\mathrm{Ca}^{2+}$ dependent. Each bar represents the mean of 5 experiments.
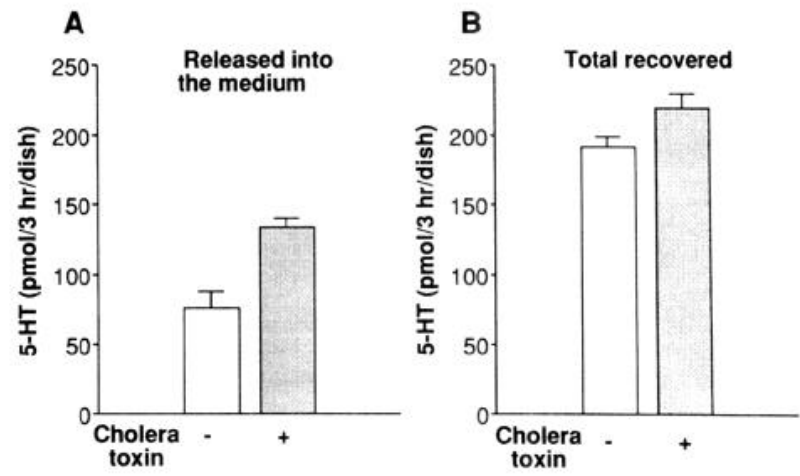

Figure 5. Cholera toxin $(1.0 \mu \mathrm{g} / \mathrm{ml})$ increases both release of $5-\mathrm{HT}$ from MTC cells and its biosynthesis. A, The release of 5-HT to the ambient medium is plotted for MTC cells incubated for $3 \mathrm{hr}$ in the presence (pluses) or absence (minuses) of cholera toxin. $B$, The total recovery of 5-HT in the cells and medium is plotted for MTC cells incubated for $3 \mathrm{hr}$ in the presence (pluses) or absence (minuses) of cholera toxin.

\section{Effect of TSH, elevated $\left[\mathrm{Ca}^{2+}\right]_{\mathrm{e}}$, and elevated $\left[\mathrm{K}^{+}\right]_{\mathrm{e}}$ on the secretion of 5-HT}

Both TSH and increased $\left[\mathrm{Ca}^{2+}\right]_{e}$ have been demonstrated to induce 5-HT secretion by PF cells (Barasch et al., 1988). The ability of these secretogogues to induce 5 -HT secretion by MTC cells was therefore investigated. Initial studies were performed to ascertain whether MTC cells, like parafollicular cells, have TSH receptors. This question was studied immunocytochemically using 2 different MAbs to TSH receptors. Assymetric accumulations of immunoreactive material were found on the surfaces of most MTC cells with both of these antibodies (Fig. $6 A$ ). A small subset of MTC cells lacked immunoreactivity. Immunoreactivity was not apparent when cells were exposed to an unrelated MAb as a control (Fig. 6B). Because these observations indicated that most MTC cells do indeed have TSH receptors, additional studies were carried out to determine whether TSH stimulates MTC cells to secrete 5-HT. The cells were exposed to TSH for $10 \mathrm{~min}$. TSH increased the rate of 5-HT release in a concentration-dependent manner (Fig. 7). This action of TSH was $\mathrm{Ca}^{2+}$ dependent. The ability of increased $\left[\mathrm{Ca}^{2+}\right]_{e}$ to act as a 5-HT secretogogue in MTC cells was investigated similarly. When $\left[\mathrm{Ca}^{2+}\right]_{e}$ was elevated, the rate of release of 5-HT from MTC cells increased (Fig. 8). If the release of $5-\mathrm{HT}$ at a $\left[\mathrm{Ca}^{2+}\right]_{e}$ of $0.01 \mathrm{~mm}$ is taken as the baseline, then the release of $5-\mathrm{HT}$ was increased by $33 \%(p<0.01)$ at a $\left[\mathrm{Ca}^{2+}\right]_{c}$ of $3.0 \mathrm{~mm}$ and by $100 \pm 10 \%(p<0.005)$ at a $\left[\mathrm{Ca}^{2+}\right]_{e}$ of $7.0 \mathrm{~mm}$. 5-HT secretion was also found to be stimulated by increasing the $\left[\mathrm{K}^{+}\right]_{e}$ to $56 \mathrm{~mm}(30 \pm 4 \% ; p<0.01)$. The release of 5 -HT induced by elevating $\left[\mathrm{K}^{+}\right]_{e}$ was comparable to that which followed addition of TSH. These data provide evidence that both TSH and $\left[\mathrm{Ca}^{2+}\right]_{e}$ act as secretogogues for MTC cells as they do for PF cells. The data also suggest that secretion by MTC cells may also be stimulated by depolarization with $\mathrm{K}^{+}$.

\section{Effect of TSH and elevated $\left[\mathrm{Ca}^{2+}\right]_{\mathrm{e}}$ on the intracellular level of cAMP}

While TSH has been demonstrated to increase $\left[\mathrm{Ca}^{2+}\right]_{i}$ in PF cells (Barasch et al., 1988), the effects of neither TSH nor $\left[\mathrm{Ca}^{2+}\right]_{e}$ have previously been determined on levels of cAMP either in the parent PF cells or in MTC cells. MTC cells were therefore exposed to $\mathrm{TSH}(50 \mathrm{mU} / \mathrm{ml})$ or $7.0 \mathrm{mM}\left[\mathrm{Ca}^{2+}\right]_{e}$ for $20 \mathrm{~min}$ at $37^{\circ} \mathrm{C}$, 


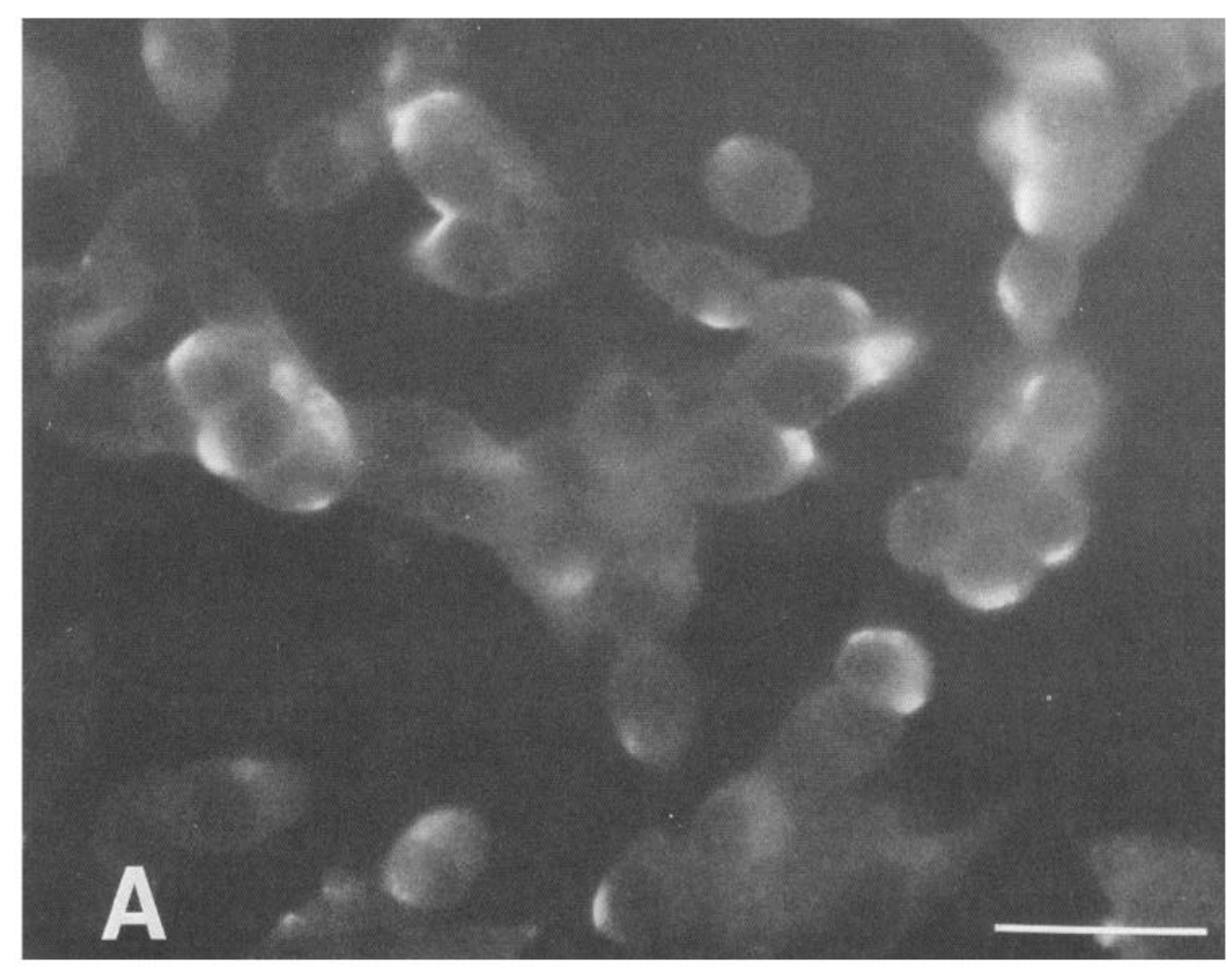

Figure 6. MTC cells display TSH receptor immunoreactivity. $A$, Cells were exposed to MAb 52A8, which reacts with rat TSH receptors. Bright patches of immunofluorescence are seen asymmetrically distributed on the surfaces of many of the cells. $B$, Control: Cells were exposed to an unrelated MAb. Only background fluorescence can be observed. Scale bars, $30 \mu \mathrm{m}$.

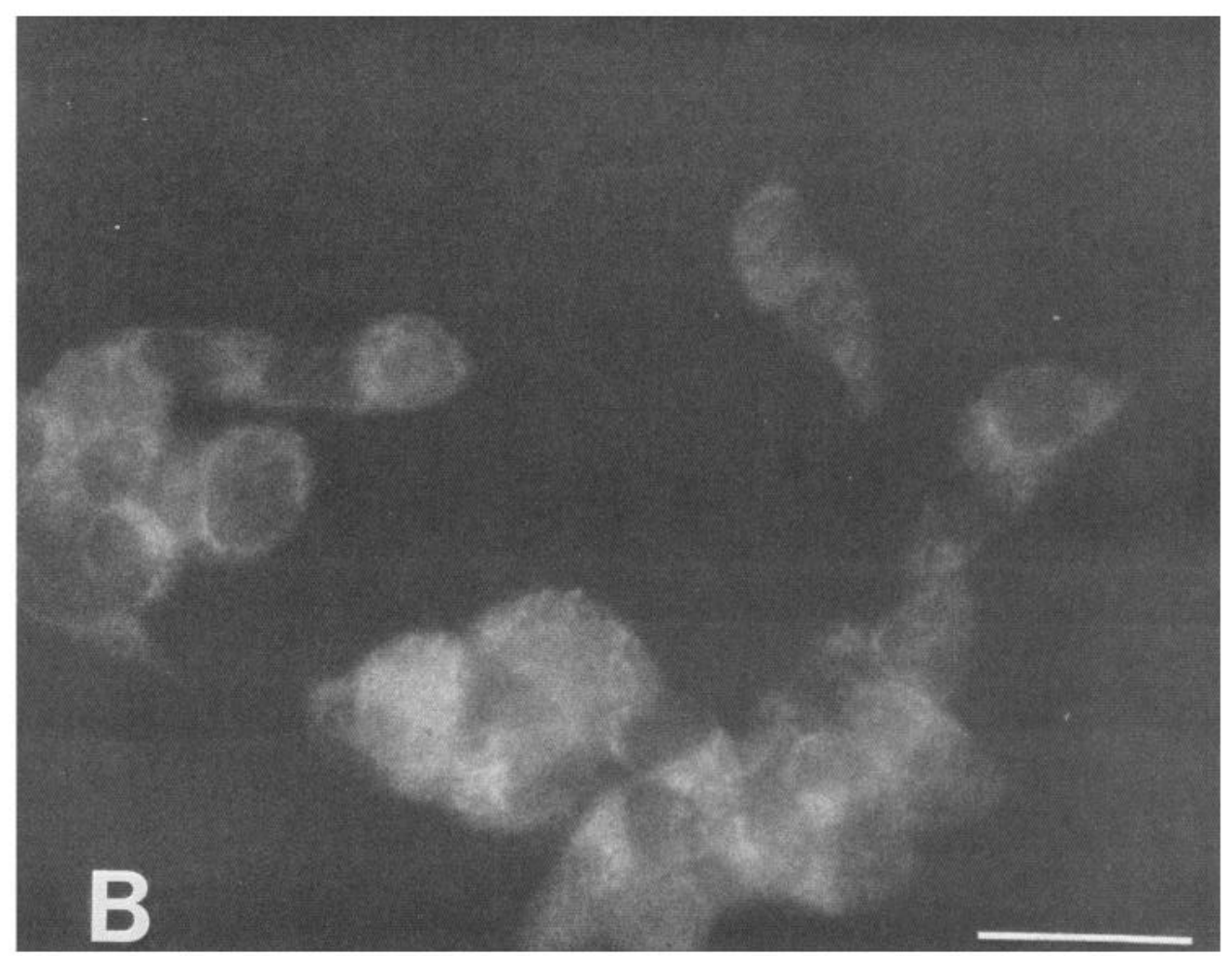

and cAMP levels were measured by radioimmunoassay. These concentrations of the secretogogues each induced a brisk secretion of 5-HT (Figs. 7, 8). Neither the addition of TSH nor the elevation of $\left[\mathrm{Ca}^{2+}\right]_{e}$ raised the concentration of cAMP in MTC cells from its basal level $(2.2 \pm 0.2 \mathrm{pmol} / \mathrm{well}$; Fig. $9 A)$. In contrast, forskolin $(0.1 \mathrm{~mm})$ produced a 7.2 -fold increase in the level of cAMP. The ability of TSH to increase cAMP was investigated in a follicular cell line as a positive control (Bastomsky and McKenzie, 1967). As expected, TSH increased cAMP in the follicular cells (Fig. 9B). 


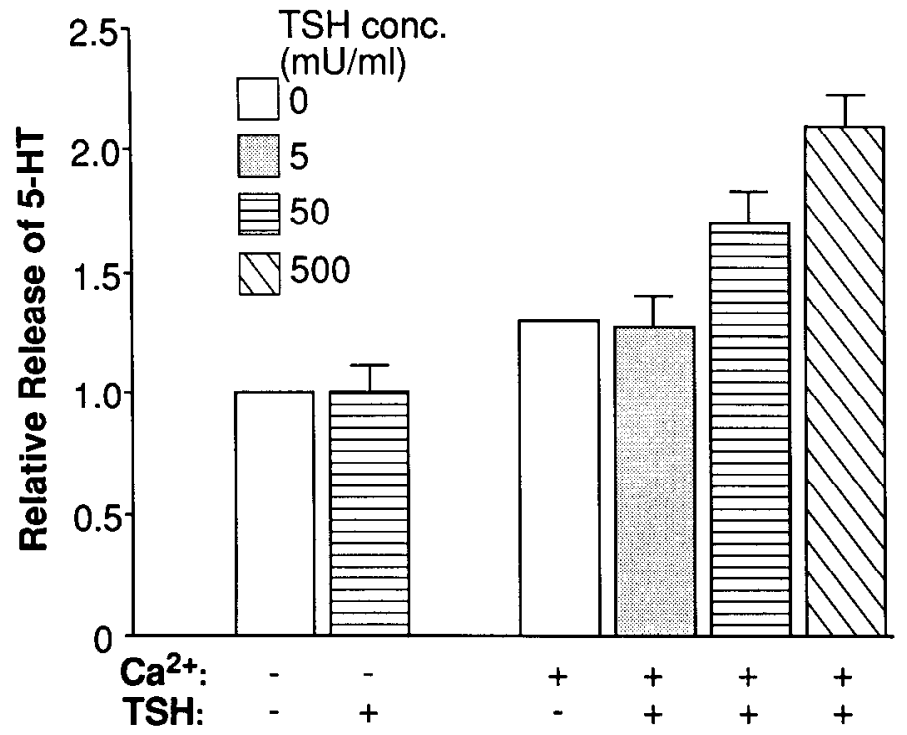

Figure 7. TSH increases release of 5-HT from MTC cells; this effect is concentration and $\mathrm{Ca}^{2+}$ dependent. The relative release of $5-\mathrm{HT}$ into the ambient medium is plotted on the ordinate, and the prevailing experimental conditions are indicated on the abscissa. Relative release is defined as a multiple of the amount of 5-HT released in the absence (minuses; pluses, presence) of $\mathrm{Ca}^{2+}$ and TSH $(1.5 \mathrm{pmol} / \mathrm{min} / \mathrm{dish})$. Each bar represents the mean of 7 experiments.
Effect of TSH, elevated $\left[\mathrm{Ca}^{2+}\right]_{\mathrm{e}}$, and elevated $\left[\mathrm{K}^{\prime}\right]_{\mathrm{e}}$ on $\left[\mathrm{Ca}^{2+}\right]_{\mathrm{i}}$ in MTC cells

To determine if TSH raises [ $\left.\mathrm{Ca}^{21}\right]_{i}$, MTC cells loaded with Fura-2 were treated with TSH $(100 \mathrm{mU})$ in $\mathrm{MEM}$ without added $\mathrm{Ca}^{2+}$. The $\left[\mathrm{Ca}^{2+}\right]_{i}$ was measured fluorometrically as a function of time. The baseline $\left[\mathrm{Ca}^{2+}\right]_{i}$ was $120 \pm 10 \mathrm{nM}$. After TSH was added, $\left[\mathrm{Ca}^{2+}\right]_{i}$ increased almost immediately and remained elevated for at least $15 \mathrm{~min}$. The highest $\left[\mathrm{Ca}^{2+}\right]_{i}(195.6 \pm 16.7 \mathrm{nM} ; p<$ .002 vs. baseline) was seen $8 \mathrm{~min}$ after the addition of TSH. The ability of TSH to cause a rise in the $\mathrm{MTC}$ cell $\left[\mathrm{Ca}^{2+}\right]_{i}$ was confirmed using optical imaging of cells loaded with Fura-2 (Fig. $10 A, B)$. This tcchnique revealed that the MTC cell population was heterogeneous with respect to the magnitude of the response in different cells of the population. Optical imaging also revealed that a subset of MTC cells responded to $\mathrm{K}^{+}(75 \mathrm{~mm})$ with a rapid increase in $\left[\mathrm{Ca}^{2+}\right]_{i}$ (Fig. $\left.10 C, D\right)$. In order to determine whether the TSH-induced increase in $\left[\mathrm{Ca}^{2+}\right]_{i}$ was due to the release of $\mathrm{Ca}^{2+}$ from an intracellular source or to $\mathrm{Ca}^{2+}$ entry from

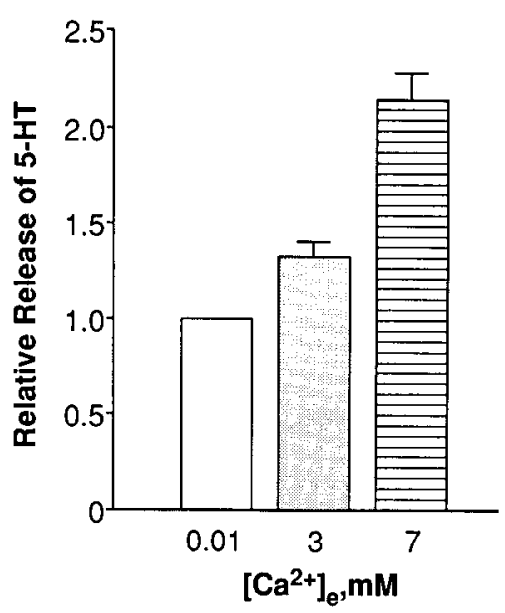

Figure 8. Elevation of $\left[\mathrm{Ca}^{2+}\right]_{e}$ causes concentration-dependent release of 5-HT from MTC cells. Relative release is defined as a multiple of the amount of $5-\mathrm{HT}$ released when the $\left[\mathrm{Ca}^{2+}\right]_{e}$ was $0.01 \mathrm{~mm}(1.1 \mathrm{pmol} /$ $\mathrm{min} / 10^{6}$ cells). Each bar represents the mean of 3 experiments. the extracellular fluid, MTC cells were exposed to TSH in the presence of EGTA. The concentration of $\left[\mathrm{Ca}^{2+}\right]_{i}, 97 \pm 10 \mathrm{nM}$, in the EGTA-containing media was not significantly changed by adding TSH. It is concluded that TSH increases $\left[\mathrm{Ca}^{2+}\right]_{i}$ by facilitating $\mathrm{Ca}^{2+}$ influx.

The $\left[\mathrm{Ca}^{2+}\right]_{i}$ of MTC cells was found to be influenced by the $\left[\mathrm{Ca}^{2+}\right]_{e}$, even in the absence of TSH. Although similar values for $\left[\mathrm{Ca}^{2+}\right]_{i}$ were obtained when Fura-2-loaded MTC cells were incubated in EGTA-containing media or in MEM without added $\mathrm{Ca}^{2+}\left(\left[\mathrm{Ca}^{2+}\right]_{e} \cong 10 \mu \mathrm{M}\right)$, the $\left[\mathrm{Ca}^{2+}\right]_{i}$ increased 2-fold when the $\left[\mathrm{Ca}^{2+}\right]_{e}$ was raised to $1.5 \mathrm{~mm}$. A further increase (to 3.5 -fold) in $\left[\mathrm{Ca}^{2+}\right]_{i}$ occurred when the $\left[\mathrm{Ca}^{2+}\right]_{e}$ was raised to $7.0 \mathrm{~mm}$. Elevated external $\mathrm{Ca}^{2+}$, like TSH, therefore increases the $\left[\mathrm{Ca}^{2+}\right]_{i}$ of MTC cells. The effects of TSH, elevated $\left[\mathrm{K}^{+}\right]_{e}$ and elevated $\left[\mathrm{Ca}^{2+}\right]_{e}$ on
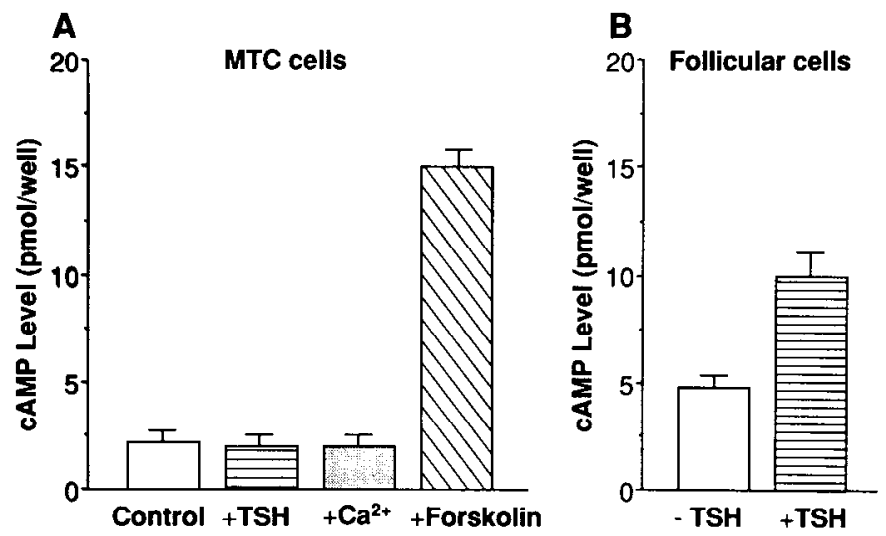

Figure 9. Effects of TSH and elevated $\left[\mathrm{Ca}^{2+}\right]$ on levels of cAMP in MTC cells and follicular cell line. $A$, Radioimmunoassay of cAMP levels in MTC cells. MTC cells $\left(5 \times 10^{5}\right)$ were grown in serum-containing media and exposed to TSH $(50 \mathrm{mU})$, elevated $\left[\mathrm{Ca}^{2+}\right]_{e}(7 \mathrm{mM})$, or forskolin $(0.1 \mathrm{mM}$ ) for $20 \mathrm{~min}$. Only forskolin increased cAMP. $B$, Radioimmunoassay of cAMP levels in a follicular cell line (FRTL-5). These cells $\left(4 \times 10^{4}\right)$ were grown in DMEM supplemented with $5 \%$ calf serum and a 6 -hormone mixture for $5 \mathrm{~d}$. The cells were washed and maintained in the same medium without TSH for another $2 \mathrm{~d}$. Cells were treated with TSH $(50 \mathrm{mU})$ for $20 \mathrm{~min}$, and the level of cAMP was measured. Each bar represents the mean of 3 experiments. 

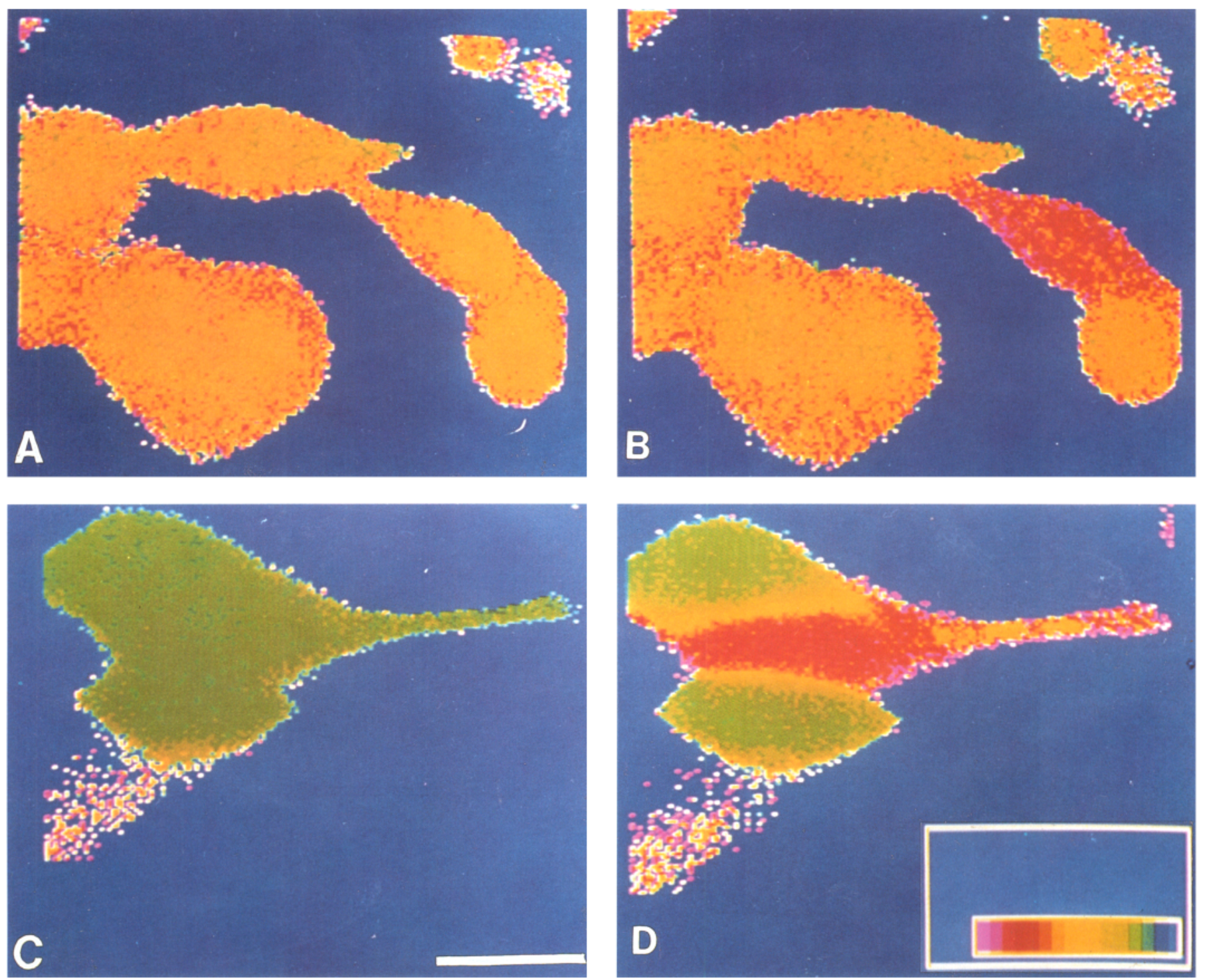

Figure 10. Ratio images of cultured MTC cells loaded with Fura-2 during either TSH or KCI stimulation. Cells were cultured for 1 week in enriched media and, after loading with Fura-2, were stimulated either with $50 \mathrm{mU} / \mathrm{ml} \mathrm{TSH}$ for $5 \mathrm{~min}(A)$ or $6 \mathrm{~min}(B)$ or with $112 \mathrm{~mm} \mathrm{KCI}$ for $2 \mathrm{~min}(C)$ or $3 \mathrm{~min}(D)$. Scale bar, $10 \mu \mathrm{m}$.

$\left[\mathrm{Ca}^{2+}\right]_{i}$ appeared not to be mediated by cAMP, because no change in $\left[\mathrm{Ca}^{2+}\right]_{i}$ was noted after addition of dibutyryl-cAMP (1.0 mM).

\section{Location of 5-HT, 45-kDa SBP, and calcitonin} immunoreactivities in the secretory granules of MTC cells

In the parent PF cell, 5-HT, 45-kDa SBP, and calcitonin are all located in secretory granules. Experiments were therefore carried out to see if the same relationship holds for MTC cells. Colocalization of each of these substances in the same secretory granules would indicate that all 3 would probably be simultaneously released from the cells by secretogogues. The immunoreactivities of 5-HT, $45-\mathrm{kDa}$ SBP, and calcitonin were visualized with colloidal gold on material embedded in a hydrophilic resin. Because the antibodies to 5-HT and calcitonin were raised in different species, 5-HT immunoreactivity was demonstrated simultaneously with that of calcitonin using species-specific secondary antibodies and different-sized particles of colloidal gold. 5-HT and calcitonin were found to be colo- calized in the same secretory granules (Fig. 11A). Calcitonin immunoreactivity was more intense than that of 5-HT. SBP immunoreactivity was not studied simultaneously with 5-HT immunoreactivity because SBP immunostaining was found to be blocked when sections were exposed to antibodies to $5-\mathrm{HT}$. Nevertheless, like 5-HT and calcitonin immunoreactivities, 45kDa SBP immunoreactivity was confined to secretory granules (Fig. 11B).

\section{Discussion}

MTC cells were used as a neuronally relevant model system to study mechanisms involved in regulating the storage and release of 5-HT. MTC cells were previously demonstrated to contain 5-HT and to synthesize it from tryptophan (Tamir et al., 1989). The intracellular site of 5-HT storage in MTC cells has not heretofore been directly demonstrated, though the reserpine sensitivity of the 5-HT storage mechanism in MTC cells suggested that intracellular 5-HT might be concentrated in vesicles. In 

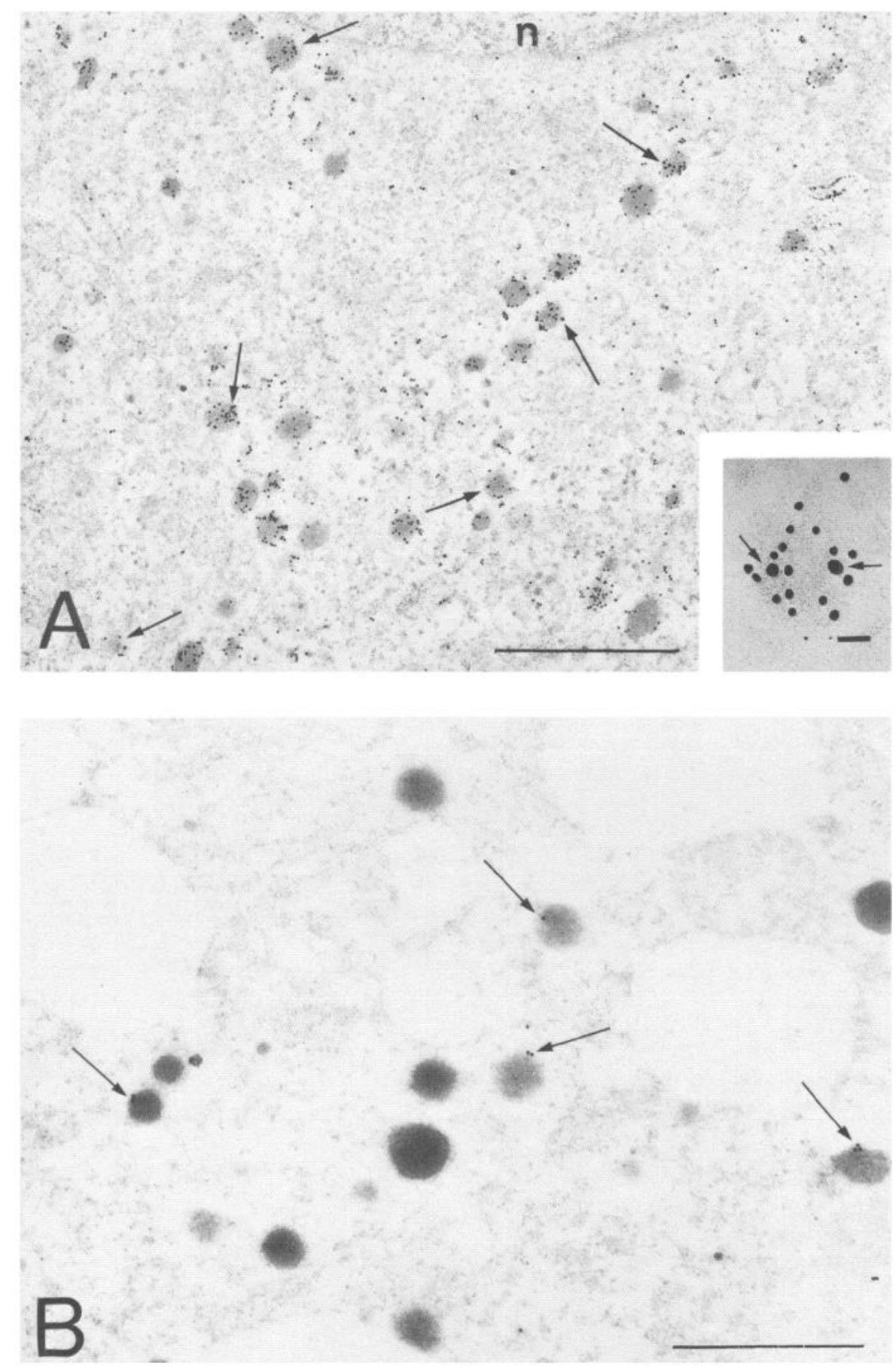

Figure 11. 5-HT and calcitonin immunoreactivities are colocalized in dense-cored granules in MTC cells: double-label immunocytochemistry with 2 sizes of colloidal gold particles. $A$, Calcitonin immunoreactivity is visualized with $5-\mathrm{nm}$ and $5-\mathrm{HT}$ immunoreactivity (arrows) is visualized with 15-nm particles of colloidal gold. Membranes are not seen because the preparation has not been exposed to osmium tetroxide. All granules show calcitonin immunoreactivity, and about $25 \%$ also display the immunoreactivity of 5-HT. Scale bar, $1.0 \mu \mathrm{m}$. $n$, nucleus. Inset, A doubly labeled granule is shown at higher magnification. The $15-\mathrm{nm}$ gold particles indicating 5-HT immunoreactivity are shown by the arrows. Scale bar, $0.2 \mu \mathrm{m}$. $B$, SBP immunoreactivity. Immunoreactivity (arrows) visualized with 5-nm particles of colloidal gold is confined to granules. Scale bar, $0.2 \mu \mathrm{m}$.

both PF cells (Barasch et al., 1988), the parent cell from which the MTC line is derived (Leong et al., 1981) and serotonergic neurons (Tamir and Gershon, 1979; Gershon et al., 1983), $5-\mathrm{HT}$ is stored in vesicles together with $45-\mathrm{kDa}$ SBP. We now find, by EM immunocytochemistry, that MTC cells contain secretory vesicles in which 5-HT immunoreactivity is costored with immunoreactive $45-\mathrm{kDa}$ SBP. MTC cells thus resemble both PF cells and serotonergic neurons in the intracellular concentration of stored 5-HT in vesicles and in its costorage with 45-kDa SBP. The functional significance of the SBP in the
5-HT storage organelles is not clear; however, the presence of the protein establishes that the secretory vesicles of MTC cells are neurectodermal in type. SBP is found only in 5-HT-storing cells that are embryologically derived from the neural tube (serotonergic neurons of the CNS) or crest (enteric serotonergic neurons and PF cells). Cells that store 5-HT but are derived from embryonic mesoderm (platelets, mast cells) or endoderm (enterochromaffin cells) lack SBP (see Gershon and Tamir, 1985). Like the secretory granules of PF cells (Barasch et al., 1988), the secretory vesicles of MTC cells also contain the immuno- 
reactivity of the peptide calcitonin; therefore, these cells retain endocrine characteristics.

$\mathrm{PF}$ cells secrete in response to exposure to TSH (Barasch et al., 1988) or elevations of $\left[\mathrm{Ca}^{2+}\right]_{e}$ (Hirsch and Munson, 1969; Gershon et al., 1978). These secretogogues were therefore used to try to evoke the secretion of 5-HT by MTC cells. Both TSH and elevated $\left[\mathrm{Ca}^{2+}\right]_{e}$ were found to induce MTC cells to release 5-HT. In each case, 5-HT secretion was $\mathrm{Ca}^{2+}$ dependent and associated with a rise in intracellular free $\mathrm{Ca}^{2+}$; therefore, MTC cells are evidently capable of releasing 5-HT by exocytosis. Secretion of 5-HT by MTC cells was also induced by treatments that elevate intracellular levels of cAMP, including exposure of cells to dibutyryl-cAMP, 8-bromo-cAMP, cholera toxin, or forskolin. Again, the release of 5-HT was $\mathrm{Ca}^{2+}$ dependent. MTC cells have also been shown to release calcitonin in response to increased intracellular cAMP (deBustros et al., 1986). Because 5-HT and calcitonin are stored in the same vesicles, exocytosis would be expected to lead to their parallel release. The current observations thus are compatible with those of previous studies. Despite the effectiveness of cAMP in inducing the secretion of 5-HT by MTC cells, neither of the physiological secretogogues, TSH nor increased $\left[\mathrm{Ca}^{2+}\right]_{e}$, raised intracellular levels of cAMP. These observations thus support the idea that $\mathrm{Ca}^{2+}$, but not cAMP, serves as a second messenger in stimulus-secretion coupling for each of the 2 natural secretogogues. Furthermore, because TSH was unable to cause a rise in $\left[\mathrm{Ca}^{2+}\right]_{i}$ in the absence of extracellular $\mathrm{Ca}^{2+}$, it seems likely that the secretogogues act by increasing the influx of $\mathrm{Ca}^{2+}$ into MTC cells, and not by releasing $\mathrm{Ca}^{21}$ from an intracellular compartment. Like TSH and elevated levels of $\left[\mathrm{Ca}^{2+}\right]_{e}$, increasing $\left[\mathrm{K}^{+}\right]_{e}$ stimulated secretion of 5-HT and a rise in $\left[\mathrm{Ca}^{2+}\right]$, in a subset of MTC cells. Increased $\left[\mathrm{K}^{+}\right]_{e}$ is likely to act by depolarizing cells. Its ability to provoke secretion and a rise in $\left[\mathrm{Ca}^{2}\right]_{e}$ thus suggests that there may be voltage-gated $\mathrm{Ca}^{2+}$ channels in the plasma membrane of MTC cells. TSH has also been shown to increase $\left[\mathrm{Ca}^{2+}\right]_{i}$ in FRTL-5 rat thyroid cells independently of the effect of the hormone on cAMP (Corda et al., 1985).

Studics of the specific activity of ${ }^{3} \mathrm{H}-5-\mathrm{HT}$ indicated that MTC cells preferentially release newly taken-up amine. The preferential release of newly taken-up biogenic amines is commonly seen in monoaminergic neurons. It has been encountered, for example, in studies of the neuronal secretion of both norepinephrine (Geffen and Jarrott, 1977) and 5-HT (Hery et al., 1979; Gershon and Tamir, 1981). The phenomenon has never been adequately explained. It may be due to the concentration of vesicles subject to exocytosis near the plasma membrane of neurons (or MTC cells), where they become selectively exposed to ${ }^{3} \mathrm{H}$-amine entering cells as a result of transmembrane transport. In fact, ${ }^{3} \mathrm{H}$-norepinephrine, newly taken up by cardiac sympathetic nerve terminals, is preferentially located in a peripheral ring of synaptic vesicles situated closest to the plasma membrane of axonal varicosities (Gershon et al., 1974). In contrast to ${ }^{3} \mathrm{H}-5-\mathrm{HT},{ }^{3} \mathrm{H}-5-\mathrm{HIAA}$ was not secreted from MTC cells in response to raising intracellular concentrations of cAMP. It is therefore most likely that only 5-HT and not its metabolite is located in vesicles and subject to exocytosis.

When the secretion of 5-HT was induced by raising intracellular levels of cAMP, the release of the amine could be antagonized by 2 different inhibitors of protein synthesis, cycloheximide and anisomycin. It is not entirely clear why the secretion of 5-HT should be dependent on protein synthesis. It should be noted, however, that the time course of 5-HT secretion induced by elevators of cAMP was extremely long. The effect was measured over a period of $3-4 \mathrm{hr}$. It is possible that protein synthesis is required for the production of new membrane protein. Conceivably, the maintenance of an increased rate of exocytosis for a long time involves considerable membrane turnover. For example, the secretion of chylomicrons by intestinal epithelial cells, another exocytotic event that continues for a comparably long duration, is also known to be dependent on new protein synthesis, which is required to provide for the increased membrane turnover involved in the secretory process (Friedman and Cardell, 1972). In contrast to its effect on secretion, inhibition of protein synthesis did not prevent the enhancement of 5-HT biosynthesis, which was also induced by increasing intracellular cAMP. In fact, inhibition of protein synthesis by itself increased the production of 5-HT. The mechanism of this effect is obscure. The concentration of L-tryptophan in the ambient medium in which the cells were grown $(20 \mu \mathrm{M})$ is less than the $\mathrm{K}_{d}$ of tryptophan hydroxylase $(50 \mu \mathrm{M})$; therefore, the enzyme is probably not saturated by substrate under resting conditions. As a result, the rate of synthesis of 5-HT could be raised by interventions that lead to an increase in the cytoplasmic concentration of L-tryptophan. Conceivably, inhibition of protein synthesis increases the concentration of L-tryptophan available for tryptophan hydroxylase by sparing substrate that might otherwise be incorporated into protein. Whatever the mechanism, the failure of cycloheximide and anisomycin to interfere with the cAMPinduced increase in 5-HT biosynthesis, while at the same time antagonizing secretion of the amine, suggests that the biosynthesis and secretion of 5-HT are separately regulated. Because the cAMP-induced increase in the biosynthesis of 5-HT continued in the face of inhibition of protein synthesis, it is unlikely that this effect is due to an increase in the amount of tryptophan hydroxylase in the MTC cells. Activation of preexisting tryptophan hydroxylase or increased availability of L-tryptophan might be responsible. Tryptophan hydroxylase has been shown to be phosphorylated in response to dibutyryl-cAMP, an effect that increases its catalytic activity (Hamon et al., 1978). Phosphorylation of tryptophan hydroxylase has also been shown to be mediated by calcium calmodulin-dependent protein kinase (Ehret et al., 1989). Given that the effect of cAMP on the secretion and biosynthesis of 5-HT is $\mathrm{Ca}^{2+}$ dependent, it is certainly possible that the cAMP-induced increase in biosynthesis of 5-HT is mediated via calcium calmodulin. Increasing intracellular levels of cAMP have also been shown to increase the biosynthesis of calcitonin (deBustros et al., 1986). In contrast to the effect on 5-HT biosynthesis, the effect of cAMP on calcitonin production is entirely accounted for by a stimulation of the rate of transcription of calcitonin mRNA.

In addition to increased $\left[\mathrm{K}^{+}\right]_{e}$ and the natural secretogogues, TSH and elevated $\left[\mathrm{Ca}^{2+}\right]_{e}$, phorbol esters have been reported to be capable of inducing MTC cells to secrete (deBustros et al., 1986). Thus far, phorbol esters have only been demonstrated to provoke calcitonin secretion; however, because 5-HT and calcitonin are stored in the same secretory vesicles, it is likely that phorbol esters would cause 5-HT to be secreted along with calcitonin. MTC cells, therefore, would appear to have multiple transduction mechanisms leading to secretion. The involvement of cAMP provides evidence that secretion is facilitated by cAMPdependent protein kinase, and the reported action of phorbol esters supports a role in secretion for protein kinase $C$. In addition, the current observations suggesting that $\mathrm{Ca}^{2+}$ might act as a second messenger in stimulus-release coupling is compatible 
with the idea that secretion may also be enhanced by a calcium/ calmodulin-dependent protein kinase. The actions of each of these kinases should therefore be investigated in future studies.

\section{References}

Adlersberg M, Liu KP, Hsiung SC, Ehrlich Y, Tamir H (1987) $\mathrm{A} \mathrm{Ca}^{2+}$ dependent protein kinase activity associated with serotonin binding protein. J Neurochem 49:1105-1115.

Ambesi-Impiombato FS, Parks LAM, Coon HG (1980) Culture of hormone-dependent functional epithelial cells from rat thyroid. Proc Natl Acad Sci USA 77:3455-3459.

Barasch JM, Mackey H, Tamir H, Nunez EA, Gershon MD (1987a) Induction of a neural phenotype in a serotonergic endocrine cell derived from the neural crest. J Neurosci 7:2874-2883.

Barasch JM, Tamir H, Nunez EA, Gershon MD (1987b) Serotoninstoring secretory granules from thyroid parafollicular cells. J Neurosci 7:4017-4033.

Barasch JM, Gershon MD, Nunez EA, Tamir H, Al-Awqati Q (1988) Thyrotropin induces the acidification of the secretory granules of parafollicular cells by increasing the chloride conductance of the granular membrane. J Cell Biol 107:2137-2147.

Bastomsky C, McKenzie J (1967) Cyclic AMP: a mediator of thyroid stimulation by thyrotropin. Am J Physiol 213:753-758.

Blumenfeld H, Spira M, Kandel ER, Siegelbaum SA (1990) Facilitatory and inhibitory transmitters modulate $\mathrm{Ca}^{2+}$ influx during action potentials in Aplysia sensory neurons. Neuron (in press).

Bradford MM (1976) Rapid and sensitive method for the quantitation of microgram quantities of protein utilizing the principle of proteindye binding. Anal Biochem 72:248-254.

Bussolati G, Pearse AGE (1967) Immunofluorescent localization of calcitonin in the C-cells of pig and dog thyroid. J Endocrinol 37:205209.

Corda D, Marcocci C, Kohn LD, Axelrod J, Luini A (1985) Association of the changes in cytosolic $\mathrm{Ca}^{2+}$ and iodide efflux induced by thyrotropin and by the stimulation of $\alpha_{1}$-adrenergic receptors in cultured rat thyroid cells. J Biol Chem 260:9230-9236.

deBustros A, Baylin SB, Levine MA, Nelkin BD (1986) Cyclic AMP and phorbol esters separately induce growth inhibition, calcitonin secretion, and calcitonin gene transcription in cultured human medullary thyroid carcinoma. J Biol Chem 261:8036-8041.

Ehret M, Cash CD, Hamon M, Maitre M (1989) Formal demonstration of the phosphorylation of rat brain tryptophan hydroxylase by $\mathrm{Ca}^{2+} /$ calmodulin-dependent protein kinase. J Neurochem 52:18861891.

Falck B, Larson B, Mecklenburg CV, Rosengren E, Svenaeous K (1964) On the presence of a second specific cell system in mammalian thyroid gland. Acta Physiol Scand 62:491-498.

Friedman HI, Cardell RR (1972) Effect of puromycin on the rat intestinal cells during fat absorption. J Cell Biol 52:15-40.

Geffen LB, Jarrott B (1977) Cellular aspects of catecholaminergic neurons. In: Handbook of physiology, Vol 1 (Brookhart JM, Mountcastle VB, Kandel ER, Geiger SR, eds), pp 521-571. Bethesda, MD: Am Physiol Soc.

Gershon MD, Nunez EA (1970) Histochemical and radioautographic studies of serotonin and parafollicular cells in the thyroid gland of the prehibernating bat. Endocrinology 86:160-166.

Gershon MD, Tamir H (1981) Release of 5-hydroxytryptamine from resting and stimulated enteric neurons. J Neurosci 6:2277-2286.

Gershon MD, Tamir H (1985) Peripheral sources of serotonin and serotonin binding proteins In: Serotonin and the cardiovascular system (Vanhoutte PM, ed), pp 15-26. New York: Raven.

Gershon MD, Belshaw BE, Nunez EA (1971) Biochemical, histochemical and ultrastructural studies of thyroid serotonin, parafollicular and follicular cells during development in the dog. Am J Anat 132:5-20.

Gershon MD, Hagopian M, Nunez EA (1974) An electron microscopic radioautographic study of the neuronal and extraneuronal localization of labeled amine in the heart of the bat following administration of tritiated norepinephrine. J Cell Biol 62:610-624

Gershon MD, Kanarek D, Nunez EA (1978) Calcium induced release of 5-hydroxytryptamine from thyroid lobes in vitro and accompanying ultrastructural changes in parafollicular and follicular cells. Endocrinology 103:1128-1143.

Gershon MD, Liu KP, Karpiak SE, Tamir H (1983) Storage of serotonin in vivo as a complex with serotonin binding protein in central and peripheral serotonergic neurons. J Neurosci 3:1901-1911.

Gill D, Meren R (1978) ADP-ribosylation of membrane proteins catalysed by cholera toxin: basis of the activation of adenylate cyclase. Proc Natl Acad Sci USA 75:3050-3054.

Grynkiewicz G, Poenie M, Tsien RY (1985) A new generation of calcium indicators with greatly improved fluorescence properties. J Biol Chem 260:3440-3450.

Hamon M, Bourgoin S, Hery F, Simonnet G (1978) Activation of tryptophan hydroxylase by ATP, magnesium and calcium. Mol Pharmacol 14:99-110.

Hery F, Simonnet G, Bourgoin S, Soubrie P, Artaud F, Hamon M, Glowinski J (1979) Effect of nerve activity on the in vivo release of $\left[{ }^{3} \mathrm{H}\right]$ serotonin continuously formed from $\left.\mathrm{L}-{ }^{3} \mathrm{H}\right]$ tryptophan in the caudate nucleus of the cat. Brain Res 169:317-334.

Hirsch PF, Munson PL (1969) Thyrocalcitonin. Physiol Rev 49:548622.

Jaim-Etcheverry G, Zeiher LM (1968) Cytochemical localization of monoamines stores in sheep thyroid gland at the electron microscope level. Experientia 24:593-596.

Kalivas PW, Miller JS (1985) Dopamine micro injection into the nucleus accumbens: correlation between metabolism and behavior. Biochem Pharmacol 34:284-286.

Kirchgessner AL, Gershon MD, Liu KP, Tamir H (1988) Co-storage of serotonin binding protein with serotonin in the rat CNS. J Neurosci 8:3879-3890.

Leong SS, Horoszewicz JS, Shimaoka K, Friedman M, Kawinski E, Song MJ, 7eigel R, Chu TM, Baylin S, Mirand EA (1981) A new cell line for the study of human medullary thyroid carcinoma. In: Advances in thyroid neoplasia (Andreoli M, Monaco F, Robbins J, eds), pp 95-108. Rome: Field Educational Italia.

Liu KP, Tamir H, Hsiung S, Adlersberg M, Gershon MD (1987) Prenatal development of serotonin binding protein in relation to other transmitter-related characteristics of central serotonergic neurons. Dev Brain Res 32:1-41.

Machado CRS (1976) Monoamines in the C cells of the thyroid gland of callithricid primates. Histochemistry 48:187-190.

Mayer GS, Shoup RE (1983) Simultaneous multiple electrode liquid chromatography-electrochemical assay for catecholamines, indoleamines and metabolites in brain tissue. J Chromatogr 255:533-544.

Nunez EA, Gershon MD (1972) Synthesis and storage of serotonin by parafollicular $(\mathrm{C})$ cells of the thyroid gland of active, prehibernating and hibernating bats. Endocrinology 90:1008-1024.

Pearse AGE (1966) Common cytochemical properties of cells producing polypeptide hormones, with particular reference to calcitonin and the thyroid $C$ cells. Veterinariia 79:587-590.

Seaman K, Daly J (1983) Forskolin, cAMP and cellular physiology. Trends Pharmacol Sci 4:120-123.

Shie JC, Eiduson S (1973) Monoamine oxidase: isolation and characterization of multiple forms of the brain enzyme. J Neurochem 21 : 41-49.

Tamir H, Gershon MD (1979) Storage of serotonin binding protein in synaptic vesicles. J Neurochem 33:35-44.

Tamir H, Liu KP, Payette RF, Hsiung SC, Adlersberg SC, Nunez EA, Gershon MD (1989) Human medullary thyroid carcinoma; characterization of the serotonergic and neuronal properties of the neuroectodermally derived cell line. J Neurosci 9:1199-1212.

Tschopp FA, Tobler PH, Fischer JA (1984) Calcitonin gene-related peptide in the human thyroid, pituitary and brain. Mol Cell Endocrinol 36:53-57. 